\title{
NYADRAN AND SOCIAL STATUS Case Study of the Efforts of Local Village Elites in the Field of Religion in Maintaining Social Status in the Javanese Muslim Community
}

\author{
Tadjoer Ridjal ${ }^{1}$, Julian Adam Ridjal ${ }^{2}$, Humaidah Muafiqie ${ }^{3}$, Effy Indriati ${ }^{4}$, Suko Susilo ${ }^{5}$ \\ 1. Department of Sociology, University of Darul 'Ulum Jombang \\ 2. Department of Agribusiness, University of Jember \\ 3. Department of Economics, University of Darul 'Ulum Jombang \\ 4. Department of Agriculture, University of Darul 'Ulum Jombang \\ 5. Department of Da'wah, Islamic Institute of Tribakti Kediri
}

\begin{abstract}
This research was conducted in a village which is a Javanese Muslim community. This research is a continuation of previous research, but with a different focus. The focus of attention in this study is the emergence of the ritual movement of nyadran (grave pilgrimage) to the graves of the ancestors of the village founders which is carried out collectively and routinely. By using a qualitative approach, field phenomena show that the social stratification system in the village where the research is located shows conditions that are starting to fade. Related to the conditions of social life, it creates collective nyadran ritual movement. A number of villagers participated in the event, and their attendance was voluntary. The guides and those who lead this activity come from family group members who occupied a high social status in the community when the village was founded. Apparently, the revitalization of traditions has a function to maintain the pattern of social stratification of rural communities.
\end{abstract}

Keywords: Nyadran, Social status, Javanese Muslim Community

DOI: $10.7176 / \mathrm{JRDM} / 82-03$

Publication date: January $31^{\text {st }} 2022$

\section{INTRODUCTION}

This study follows up on the findings of Ridjal et al's (2021) study conducted in Sumberarum village, Jombang district, East Java. All the residents of this village are Muslim. As in most rural areas, most of these rural communities work in the agricultural sector, so that the lifestyle of the farming community is more colorful in the village life. The characteristics of a stratified agrarian society - as stated by Sanderson (1995) - also appear in this village. It seems that the pattern of social stratification in this village has been established since the beginning of the village, which is related to the ownership of agricultural land. This is in line with what was stated by Wahyono (2017) in his study that the $19^{\text {th }}$ century Javanese society was not a homogeneous society, but was a complexly differentiated society in patterns of land ownership, and land tenure determined the social stratification of the owners.

Ridjal et al. $(2019,2021)$ stated that in the early days of the village, the residents of Sumberarum were divided into three identity groups. The identity group is more a symbol of kinship or descent groups, namely: wong njero, wong njaba and wong mambu-mambu. Members of the descendants of the founding family of the village, are then given a symbol of the identity of wong njero by the community. The members of the village community who are considered to have no kinship with the founding family of the village are given the symbol of the identity of the wong njaba. Meanwhile, wong mambu-mambu considers himself to still have a kinship with wong njero .

In the early days of the village, the main source of meeting the economic needs of rural communities was the agricultural sector. It seems that the difference in the designation of the identity groups is not only based on kinship relations, but also on the control of agricultural land. Members of the wong njero family and those related to the wong njero family control most of the village's agricultural land. Lenski (1966) concludes that if there is a surplus and the struggle for control is unavoidable, the surplus will be controlled by the most powerful individual or group. Thus, it is the economic surplus that causes stratification to develop. Perhaps it is this economic factor that makes the wong njero family group occupies a high social status in the village community.

Over time, a number of villagers - including most of the wong njaba residents - no longer depended on the agricultural sector for their livelihood. Moreover, a number of factories have been built in areas that are only a few kilometers from the village of Sumberarum. Thus, a number of residents from among the wong njaba prefer to work as factory workers. Several others work as itinerant vegetable traders, motorcycle taxi drivers, carpenters, stone masons, and so on.

In addition, the control of agricultural land among the wong njero is no longer centered on one or two people. The process of inheritance causes the ownership of agricultural land to experience fragmentation. In fact, a number of agricultural lands have been converted into residential areas. With the change in the situation, from the economic dimension - especially the traditional rural economic relations - the wong njero no longer control 
one of the dimensions of stratification building.

Based on the fact that the stratification system in Sumberarum has begun to fade, what attracts attention in this study is the emergence of the ritual movement of nyadran (grave pilgrimage) to the tombs of the ancestors of the village founders. The tradition of nyadran or sadranan according to Prasetyo (2010) is a tradition carried out by Javanese people every time before Ramadan fasting, which is carried out in the month of Sha'ban (Hijriyah calendar) or Ruwah (Javanese calendar) to express gratitude which is done collectively by visiting graves. However, the nyadran tradition that emerged in this research location no longer follows the general rules. This ritual is initiated by the descendants of the village founders, or members of the wong njero circles. This ritual is carried out regularly every Tuesday Pon (or every 35 days, following the Javanese calendar), and is followed by most of the people among the wong njaba. In this regard, the question of this study is: "Why do the wong njero carry out the nyadran ritual routinely to the tomb of the village founder?"

\section{RESEARCH FRAMEWORK AND METHODOLOGY}

This study uses socialization theory to understand the field phenomena. This is based on the idea that the revitalization of tradition cannot be separated from the socialization of the tradition itself. Because of the unique human ability to learn, in general the socialization process is very important. Sanderson (1995) stated that socialization is a process in which humans try to absorb the contents of the culture that developed in their place of birth. In line with Sanderson, the general process of acquiring culture is referred to as socialization, or as the process of induction of individuals into the social world. The term socialization refers to the process of interaction in which a growing individual learns the habits, attitudes, values, and beliefs of the social group into which he or she is born. Berger and Luckmann (1966) define primary socialization as the first socialization that individuals undergo during childhood by learning to become members of society (family). Conklin (1984) asserted that through the process of socialization, community members learn the culture of that society and participate fully in that society. Gertrudge Jaeger, citing Uri Bronfenbrenner and Melvin L. Kohn, states that socialization can be divided into two patterns, namely; repressive socialization and participatory socialization (in Sunarto, 2004).

Most social scientists believe that this process makes the older generation spends a great deal of time transmitting culture to the succeeding generations, and the succeeding generations usually receive a great deal of impressions from these teaching efforts. With regard to the transmission of culture between generations, Kleden (1986) is of the view that by relying on tradition and integration, a culture will maintain its identity, ensure its continuation. Furthermore, Williams views tradition as the surviving past (1977). Thus, the process of socializing tradition is related to the background of the context of tradition production itself, both in terms of temporality and spatiality.

The survival of a tradition as the surviving past is highly dependent on socialization. Tradition in practice is actually an expression of restrictions and pressures those hegemonies and domination. The hegemonic ideology is a system of ideas that dominate people's thinking patterns, but originates from, and benefits the upper layers of society. The hegemony thesis developed by Gramschi as stated by Bocock (1986) shows that the control mechanism used by the ruling group to maintain its superiority is not only limited to control over the means of production, but more importantly control through ideological hegemony. According to Lull, ideology itself is a system of ideas expressed through communication (in Andriana, 2011). Based on Gramschi's view, through ideological hegemony obedience can be forced and resistance can be broken or eliminated by the ruling group (Flank, 2007). This thesis holds that the ruling group can become the most influential group only to the extent that its ideology is able to accommodate, and give room to the culture and values of the opposing group.

Following this view, the hegemonic process is never perfect in itself, but always negotiated. This is similar to the results of the Takbir study (2018) that ideological negotiations produce new forms. Likewise, Dwiwardani and Setyaningsih states that in hegemony there is always negotiation and transformation (2021). The ruling group tries to win hegemony, while the controlled group tries to survive through counter hegemony (Flank, 2007). Especially if the group controlled is the poor. As stated by Mitchell (1990) that the powerful group can only control the outward behavior of the poor, not their thoughts. Therefore, Faucoult (1994) shows that where there is power, there is resistance.

The socialization can be divided into two patterns, namely participatory socialization and repressive socialization. Therefore, the process of traditional socialization is highly dependent on the choice of the right strategy. The consideration is the choice of a particular strategy is very likely to be seen by members of the community as a cultural intrusion that will become dissonance of established cognitive structure. This can encourage them to try to maintain the stability of their cognitive structure. Efforts to maintain the stability of the cognitive structure is not without risk. In other words, repressive ways of socializing tradition can lead to community resistance. On the other hand, participatory socialization methods allow for support from the community.

Following the views of Miles et al, (2014), Tracy (2013), and Yin (2011), this study uses a qualitative approach. Studies like this according to Ridjal (2003) have the aim to explore or building a proposition or 
explaining the meaning behind reality. Researchers are based on the reality that occurs in the field, namely the life of a collective nyadran tradition which was originally only carried out once a year, now it is carried out every Tuesday Pon (every 35 days). What is encountered in this study is the social world of everyday life.

This study seeks to see what is happening in the world and embed the findings obtained in it. Therefore, what is done while in the field is included in a case-based, ideographic, and emic position, which directs attention to the specifics of certain cases. The meaning of social phenomena - through the method of self-intersubjectives - is emphasized, but the objective conditions of socio-cultural life are not ruled out (Ridjal, 2003).

This study focuses on everyday cultural life. In this regard, this study area emphasizes the cultural traditions that live in the community, namely the collective nyadran tradition which has become a routine ritual activity every 35 days, or every certain market day according to the Javanese calendar. These cultural traditions are the basis for data collection. This study also considers Anderson and Jack's assertion that the nature and extent of the community is largely a matter of individual definition (1991). Thus, the representatives of these study units that emphasize data collection are the procedures for its implementation, the values that underlie it, and more importantly the understanding or meaning of individuals as members of the community towards the nyadran tradition .

In the field data collection process, a number of informants were involved in this. They not only assist in collecting data, but also assist in clarifying field data or to cross check field data. The collected data is then interpreted taking into account the understanding of the informants. If there is a difference in interpretation of the data about the same event, try to clarify it again on another occasion by involving more informants. In this case, informants who live outside the study location villages are also very likely to be involved. This step emphasizes the application of field data consistency and congruence techniques. Merriam (1995) and Lincoln and Guba (1985) use congruence term for internal validity, and consistency or dependability for the reliability of qualitative study data.

The results of data collection in order to achieve a high level of consistency and congruence, the researchers followed the directions of Adler and Adler, namely: using the "multiple observers" strategy, conducting data relevance tests through discussions with peers and seminars, using various data collection techniques from various sources and involved in the situation of the study site (1994). The data analysis uses the stages of the flow model from Miles and Huberman (1994), namely data collection, data reduction, data presentation, and verification that run simultaneously, or take place simultaneously with the data collection process.

\section{DATA AND DISCUSSION}

This study focuses on the local cultural elite, more specifically the religious field in rural Java. Studies that examine rural local elites generally focus on the political elite or formal elite in the village. An article from Sri Nugroho and Fimmastuti (2020) discusses the role of local elites in mobilizing community participation in various development programs. Meanwhile, a study conducted by Adi Pradana (2019) shows how important social relations in the local cultural aspect are between the elite and the owner of the langgar, where the langgar which is a cultural institution is used as a political mapping tool. Amin (2017) explained and mapped the social relations between the community and the village government and how the community participated in the government itself. Meanwhile, what is done by Cahyono et al., (2005) focuses on local political elites and formal elites - other formal elites in the village. Meanwhile, Muhammad Fadli et al (2018) in his study not only focused on local political elites, but also religious and traditional leaders.

The village where this study was conducted has experienced a process of santrinization. That's why the nyadran tradition is part of the cultural life of the community. Along with the period of santrinization, the main ritual in the nyadran is tahlilan, which is a reading whose composition consists of several verses of the Qur'an, shalawat, tahlil, tasbih and tahmid, the reward of which is given to people who have died, with a reading procession which is more often done collectively (in congregation). In Javanese society, according to Maeyulisari (2020) the nyadran tradition has a positive value, namely building harmony between people. The same thing was conveyed by Satria (2017) in his study.

In the early days of santrinization, the people of Sumberarum were divided into three identity groups, namely: wong njero, wong njaba and wong mambu-mambu. These identity differences affect the pattern of social relations between identity residents. However, the pattern of social relations that occurs in Sumberarum is more accurately referred to as status differences, not class differences. The identities of local sub-cultures that developed in this research location are not just differentiation. In the beginning, these identities were more related to differences in descent groups and the residential locations of their members. In its development, these local subcultural identities turned into status groups, although they did not lead to social class. This is based on the social stratification system that developed in this village.

Class and status are indeed different, at least since Marx put forward his conception of class. Holt (2015) states that differences in class interests are used in the context of analyzing social inequality rooted in economic conditions. Suseno (2010) says that according to Lenin, social class is considered as a social group in a social 
order which is determined by a certain position in the production process. Slaughter (1975) adds something similar to what Marx argued that class is rooted in social relations of production, not relations in distribution and consumption. Furthermore, Suseno (2010) explains,

According to Marx, the main actors in social change are not individuals, but social classes. In every society there is a ruling class and a controlled class or in other words there is an upper class and a lower class. Marx divided the social class into three classes, namely the workers, the owners of capital and the landlords. However, in a capitalist society, landlords are included in the owners of capital.

In addition, Bendix and Lipset (1963) also describe their views on class as follows:

"... class according to Marx refers to a collection of people who perform the same function in the organization of production, classes in a society are distinguished from one another based on differences in positions in the economic order, namely differences in positions in domination. production tools.

This is confirmed in Lloyd Warner's analysis that the index of status traits determines class size based on the social and economic conditions of each member of the community (Rahman, 2011).

Another opinion states that social class or social class refers to hierarchical differences (or stratification) between human beings or groups of people in society or culture. Usually most people have social groups (Habermas, 2006), but not all communities have the same types of social group categories. Based on the characteristics of social stratification, there are several divisions of class or class in society. Adam Smith's conception (in Gordon, 1991) which divides society into three main groups, namely land providers, capitalists, and laborers is included in a non-contradictory model of dependency scheme. Some traditional hunter-gatherer societies have no social class and often have no permanent leader. Therefore, such a society avoids social stratification (Gowdy, 2006). In such a society, everyone usually does the same activities and there is no division of labor .

Based on the diversity of interpretations, especially if the above conception is applied in farming community like Sumberarum, it is difficult to find a formal definition of class. This is as experienced by Beteille (1979) in his study of an agrarian society in India when he tried to formulate a formal definition of what is called class by comparing the various models of interpreting the existing class structure with the social reality found by him. Therefore, Shanin (1982) explains that there is no concept of social stratum that can be used to accurately capture the social reality of a particular farmer group. Thus, the effort to develop a conceptual understanding of the farming community is a very difficult problem.

As mentioned above, the pattern of social relations among villagers in the study area is status relations. Bendix and Lipset quoting Weber's view stated that, "... as a manifestation of social stratification with regard to the principles adopted by the community concerned in consuming property as reflected by a special lifestyle." ( 1963). Thus, the social structure that developed in Sumberarum seems more appropriate to be included in the category of status differences which refers to Weber's view above.

The relations pattern between structures, or in this case between groups in Sumberarum, invites debate as to whether it is a formal or informal structure. This pattern of relationships represents a pattern of norms or expectations about how members of community groups should organize their relationships. In Easton's view (1990), the pattern of relationships between structures can be seen as part of the behavioral structure or cultural structure. Based on Easton's view, this seems to be helpful in understanding the pattern of inter-group relations that occurs in Sumberarum.

The recognition of Sumberarum as a santri village supported by the practices of various religious traditions seems to be related to the initiation of the structure which is the prescription of rules that determine the roles and actions of its members. Especially if it is related to the nyadran tradition activities that have emerged lately which are carried out regularly, every 35 days or Tuesday Pon according to the Javanese calendar. This activity is held in the afternoon, starting at 15.30 WIB until 17.00 WIB. A number of villagers participated in the event. Their attendance at the event is voluntary. In fact, some of them made donations, either in the form of money or various snacks and food. Donations of money are given to increase the cash for activity funds. Meanwhile, donations in the form of snacks and food will be eaten together by the participants after the nyadran event is over .

The religious ritual tradition stipulates a number of requirements (though not explicit) about who has the right to lead it, and how to treat the leader of the tradition. In Easton's view (1990), the conceptualization of these rules seems to only build a definition of the relationship or structure, which represents a description of the rules that relate only to behavior. However, if viewed from the crescive concept proposed by Blau and Scott (in Easton, 1990), relations between groups in Sumberarum at first seemed to be also supported by ritualistic establishments (although not explicit): about who has the right to lead it, how to treat traditional leaders. This includes the special rights inherent in it, the form of community involvement, as well as moral sanctions for counter-acculturation actors, especially in the early days of the Sumberarum santrinization. Therefore, wong njero, wong mambu-mambu, and wong njaba began to come to the fore along with the beginning of the santrinization. In 
this regard, the social structure that developed in Sumberarum can be classified as a formal structure, but a formal structure in a non-literate society.

As mentioned earlier, the division of residential locations in Sumberarum still seems to follow, citing the view of Moertono (1985), namely the conception of concentric circles of Javanese power. In such a conception, an area of power is largely determined by, not the boundaries of its territory, but by its center (mandala). The area of power always changes according to the amount of power that is concentrated at the center. In such a system does not have fixed and mapped territorial boundaries, but has boundaries that are not fixed and always changing. This can be seen from the preferential treatment, at least in the calling of subasita's clothing and the use of the language " krama " towards individuals from the wong njero circles. The call of respect was not limited to the treatment of the people living in Sumberarum, but also the people from the surrounding villages. Moreover, the santri are a line that can be relied upon in reproducing a public image regarding the respectable position and social influence of the kyai (Islamic scientist and leader) and his family. Because of the position of the kyai in the conception of the cosmic circles of kedhung agama as the axis of the religion, his family members who occupy positions around the axis of the axis enjoy special treatment from the community.

As already mentioned, the social stratification that lives and develops in the village does not only prioritize differences in the accumulation of wealth dimensions. Initially, the social stratification that lived and developed in this village was based on differences in agricultural land tenure. Most of the agricultural land in the village is owned by members of the wong njero group. However, when the control of agricultural land experienced fragmentation, then this group no longer controlled village agricultural land as in the past. However, the wong njero identity group still occupies a high social status. This can be observed from the treatment of villagers towards members of the identity group.

It is the same in the power dimension. In the early days of the emergence of differences in local sub-cultural identities, the local village political elite were indeed controlled by members of the wong njero group. This group controls power in the local political field (village head) and in the socio-religious field (kyai desa). However, since one member of this group resigned as village head, due to old age, no member of this group has any desire to run for village head. Since then the position of village head has been controlled by residents who are not members of the wong njero identity group. Nevertheless, members of the wong njero group still receive respect from the villagers in general. With the development of the life of the village community, the wong njero group no longer accumulates the dimensions of wealth and local political power as in the early days of the village. However, the respect of villagers for members of this group has not changed. This is the focus of this study.

According to legend, the ancestors of the wong njero are believed to be the founders of the village. After Sumberarum was known as the santri (Islamic student) village or kedhung agama ( religious education center, due to the establishment of the pesantren), the village kyai always came from the descendants of the village founders. Therefore, they enjoy special privileges - even if it is limited to subasita calls and the use of the Javanese Krama language, which is the refined Javanese language usually used when speaking to elders or elders. In social life in the scope of Javanese society, there are 3 kinds of languages, namely ngoko, madya, and krama. This level of language then determines the impression of respect and courtesy of the speaker.

Dhofier (1994) adds that the system of recognition as a kyai (and thus recognition as a member of a kyai group) is not obtained because of heredity, but through achievements. However, kyai have developed an established tradition that their descendants and their closest relatives have a greater chance of becoming members of the kyai group. Therefore, in Java in general, the closest members of the kyai's family are also respected, have high prestige, and often enjoy the privileges that society grants kyai. This is in line with the idea based on the conception of "concentric circles of Javanese power" inherited from Mataram II (Moertono, 1985). In this way, it can strengthen the community's assessment ( public image) that the descendants and closest family of a kyai can inherit some spiritual attributes from their ancestors, or the kyai. Public image as well as a way of giving legitimacy to the offspring and the kyai's closest family as the most legitimate successors. And, the public image is always reproduced by the students and people who have benefited from the kyai's family. Therefore, the public image still survives and lives in society.

In addition to the relationship with the attributes of kyai, differences between groups in Sumberarum are also manifested in dialogue, especially in the use of spoken communication languages, namely krama and ngoko. The use of polite language that still persists in Sumberarum indicates the strong influence of the legacy of the agrarian society of the inland kingdoms which continues to this day, namely the hierarchical structure. This kind of inheritance produces a social structure that is seen as multi-layered with groups separated from one another. The emergence of the titles wong njaba, wong njero and wong mambu-mambu was one of the results. The history of the entry of Islam to Java in the past has indeed reduced the rigid hierarchical character of the caste system. However, there is still a linguistic fact that cannot be denied, namely the existence of levels of language, especially in spoken discourse when conducting dialogue.

The whole oral discourse is characterized by different levels. Although there is a neutral vocabulary that can be used in every situation, the choice of ordinary words, both nouns and verbs, is determined by the type of social 
relationship among the speakers. Even this is also determined by the relationship between the speakers and the person they are talking about. It is no exaggeration when the early 16th century Tome Pires (in Lombard, 1996) has expressed it in the Oriental Summa,

Nowhere else in the world does his arrogance stand out as much as in Java, where there are two languages, one spoken by the nobility and the other by the people. .....

It's not a matter of decency, but the name of an object among the nobility is different, it's different among the people.

Tome Pires' testimony above is invaluable, even if he only illustrates part of the reality. What exist are not two languages side by side, but one language with two levels. The simpler forms are used by superiors, while the more complex forms (which are affixed with various politeness endings) are used by subordinates. From this phenomenon, it is assumed that there is a consequence that must be borne in the social relations of society which are structured following the stratified linguistic facts, namely the moral burden is inversely proportional to the individual's social position in the social stratification system that lives in society.

It seems that family members from the wong njero circles are trying to maintain this stratified pattern of social relations. By regularly holding the nyadran tradition, the main event of which is collective tahlilan, they are trying to revive the tradition that was mainstay in the early days of the Sumberarum santrinization. At the same time, they remind the villagers about the role of the ancestors of the village founders, who are none other than the ancestors of the wong njero. Moreover, the regular nyadran event this time was guided by family members among the wong njero. They also lead the course of this event to completion.

As already mentioned, the wong njero group no longer accumulates the dimensions of wealth and local political power as in the early days of the village. However, villagers' respect for members of this group is not expected to change. Although only limited use of the language of terraced manners by villagers in speaking to members of the wong njero. It seems that this kind of social relationship can still be maintained in the daily life of the villagers.

\section{CONCLUSION}

The main activity in the nyadran tradition in the villages where this study is located is tahlilan, as was the beginning of village santrinization. The survival of a tradition as the surviving past is highly dependent on socialization. Tradition in practice is actually an expression of restrictions and pressures that hegemony and dominates. In this regard, hegemonic ideology is a system of ideas that dominate people's thinking patterns, but originates from, and benefits the upper layers of society. However, the development of the pattern of social stratification of society is dynamic. Likewise, the existence of status groups in society.

Along with the development of society, the existence of identity groups began to blur. This new identity moves towards the collective identity of fellow villagers. However, the formerly dominant group seeks to activate a tradition to maintain its status. A culture without tradition means without identity. Tradition and identity are dialectically related. Therefore, they reinvented the tradition that had previously been the mainstay of the early period of santrinization. The center of the identity spectrum is no longer based on locality as before, namely the mosque's mandala. The center of the identity spectrum is directed at tradition. Thus, anyone who is involved in the tradition is considered sufficient to be in the ranks of the santri as in the early days of the village.

Based on that fact, reinvention of tradition - through routine collective nyadran - can only be built through a process of socialization or enculturation. However, the socialization process will be successful if it is carried out by parties who have the authority. That authority is owned by those who occupy positions or high social status in society. Those who occupy this position because they have succeeded in accumulating valuable resources in society. Based on the history of the founding of the village, those who are considered to have authority in leading ritual traditions with religious nuances are those from the wong njero circles. In this way, the wong njero family group can maintain its status position in society. Although only limited to respect in speaking when communicating between groups. Thus, the revitalization of traditions has the function of maintaining the pattern of social stratification in the village community.

\section{REFERENCES}

Adi Pradana, M.Y.; 2019, "Relasi Sosial Elit Politik dan Sesepuh Desa Melalui Langgar Di Kabupaten Malang”, Jurnal Sosiologi Agama, Vol 13, No 1: 181-206;

Adler, PA and P Adler, 1994, "Observational Techniques”, in NK Denzin and YS Lincoln (ed), Handbook of Qualitative Research, London: Sage Publications, pp. 377-391.

Amin, Khairul, Desember 2017, "Elit dan Kekuasaan Pada Masyarakat Desa: Studi Relasi Antara Pemerintah dan Masyarakat di Desa Rias Kecamatan Toboali Kabupaten Bangka Selatan Provinsi Kep. Bangka Belitung”; Jurnal Sosiologi USK; Volume 11, Nomor 2,: 167-187.

Anderson, K and D Jack, 1991, "Learning to Listen: Interview Techniques and Analyses", in S Gluck and D Patai (ed), Women's Words: The Feminist Practice of Oral History, NY: Routledge, pp. 11-26. 
Andriana, N., 2011, "Hegemoni Ideologi Dalam Konstruksi Identitas Budaya Masyarakat Melayu Riau Pada Desain Arsitektur”, Widyariset, Vol. 14 No.1,: 113-122.

Bendix, R and SM Lipset, 1963, "Karl Marx Theory of Social Classes", in (ed), Class, Status and Power: A Reader in Social Stratification, $7^{\text {th }}$ edt, Glencoe: The Free Press of Glencoe

Berger, PL and T Luckman, 1966. The Social Construction of Reality, Garden City: Doubleday

Beteille, A, 1977, Studies in Agrarian Social Structure, $3^{\text {rd }}$ edt, New Delhi: Oxford University Press.

Bocock, R, 1986. Hegemony, Chichester: Ellis Horwood Limited.

Cahyono, Heru, dan D Mashad, I H Gayatri, M. Nurhasim, S Rozi, Tri Ratnawati; 2005, "Konflik Elite Politik di Pedesaan: Relasi antara Badan Perwakilan Desa dan Pemerintah Desa”; Jurnal Penelitian Politik; Vol 2, No 1: $73-84$

Conklin, JE, 1984, Sociology, New York: Macmillan Publishing Co., Inc.

Dhofier, Z, 1982. “Tradisi Pesantren: Studi Tentang Pandangan Hidup Kyai”, Disertasi, Jakarta: LP3ES.

Dwiwardani, W dan WH Setyaningsih; 2021; "Hegemoni dan Negosiasi Dalam Gaya Berbusana”, JISH Undiksha, Vol 10, No 1, 99-116.

Easton, D, 1990, The Analysis of Political Structure, London: Routledge.

Fadli, M, dan M K Bailusy, J Nas, A Zulfikar, 2018, "Keterlibatan Elit Lokal dalam Peningkatan Partisipasi Politik pada Pemilihan Bupati dan Wakil Bupati Kabupaten Toraja Utara Tahun 2015"; Sosial Politik Humaniora, Vol. 6. No.2.: 301-328.

Flank, Lenny; 2007, Hegemony and Counter-Hegemony: Marxism, Capitalism, and Their Relation to Sexism, Racism, Nationalism, and Authoritarianism. St. Petersburg, Florida: Red and Black Publishers.

Foucault, M, 1994. "Two Lectures”, In NB Dirks, G Eley, SB Ortner (ed), Culture/Power/History: A Reader in Contemporary Social Theory, Princeton, New Jersey: Princeton University Press, pp 200-221.

Gordon, S, 1991. The History and Phylosophy of Social Science, New York: Routledge.

Gowdy, J., 2006, "Hunter-gatherers and the mythology of the market," in Richard B. Lee and Richard H. Daly (eds.), The Cambridge Encyclopedia of Hunters and Gatherers, New York: Cambridge University Press

Habermas, J., 2006. "The European Nation State - Its Achievments and Its Limits. On the Past and Future Sovereignty and Citizenship", in G. Balakrishan (ed.) Mapping the Nation. London: Vernon.

Holt, J P., 2015, The Social Thought of Karl Marx, London: Sage

Kleden, I, 1986. "Membangun Tradisi Tanpa Sikap Tradisional: Dilema Indonesia Antara Kebudayaan dan Kebangsaan", Prisma, 8 (XV): 69-86.

Lenski, G. E., 1966, Power and Privilege: A Theory of Social Stratification, New York: McGraw-Hill.

Lincoln, YS, and EG Guba, 1985, Naturalistic Inquiry, Beverly Hills, CA: SAGE.

Lombard, D; 1996, Nusa Jawa: Silang Budaya, Jakarta: Gramedia Pustaka Utama.

Maeyulisari, M., 2020, “Tradisi Nyadran Sebagai Perekat Kerukunan Antar Umat Beragama Di Dusun Kalitanjung Desa Tambaknegara Kecamatan Rawalo Kabupaten Banyumas”, Skripsi, Purwokerto: IAIN.

Merriam, SB, 1996. "What Can You Tell From an N of 1?: Issues of Validity and Reliability in Qualitative Research", Indonet, The University of Georgia.

Miles, M B. and A. M Huberman, J Saldana, 2014, Qualitative Data Analysis: A Methods Sourcebook and The Coding Manual for Qualitative Researchers; Thousand Oaks, CA: SAGE

Miles, MB, and AM Hubermann, 1994, "Data Management and Analysis Methods", in NK Denzin and YS Lincoln (ed), Handbook of Qualitative Research, London: Sage Publications, pp. 428-443.

Mitchell, J, 1990, "Everyday Metaphores of Power", Theory and Society, (19): 454-477. Moertono, S, 1985, Negara dan Usaha Bina Negara di Jawa Masa Lampau, Jakarta: Yayasan Obor.

Prasetyo, Y E, 2010, Mengenal Tradisi Bangsa, Yogjakarta: IMU

Rahman, M. T., 2011. Glosari Teori Sosial. Bandung: Ibnu Sina Press.

Ridjal, T., 2003. "Metode Bricolage Dalam Penelitian Sosial”, Dalam Burhan Bungin (editor), Metode Penelitian Kualitatif, Aktualisasi Metodologis ke Arah Ragam Varian Kontemporer, Cetakan Kedua, Jakarta: PT RajaGrafindo Persada, Jakarta, hal. 82-100.

Ridjal, T., and Suharnan, M. Farid, 2019, "Santrinization and Egalitarian Spirit: A Case Study of Santri Village Community in Jombang, Indonesia", Historical Research Letter, Vol.48,: 29-36.

Ridjal, T. and JA Ridjal, S Susilo, H Muafiqie, E Indriati, 2021, "Education and Local Elite Authority: The Study of Traditional Local Elite Strategies in Maintaining Authority of Muslim Communities in Rural Java", Journal of Education and Practice, Vol.12, No.2,: 65-72

Sanderson, SK, 1995. Sosiologi Makro: Sebuah Pendekatan Terhadap Realitas Sosial, Edisi II, Jakarta: Raja Grafindo Persada

Satria, D A., 2017, "Nilai dan Fungsi Dalam Tradisi Nyadran Di Padukuhan Gejayan, Condongcatur, Depok, Kabupaten Sleman"; Skripsi, Yogjakarta: UIN Sunan Kalojaga.

Shanin, T., 1982). "Defining peasants: Conceptualisations and de-conceptualisations: Old and new in a Marxist debate", The Sociological Review, 30(3), 407-432 
Slaughter, C., 1975, Marxism \& the Class Struggle, New Park Publications.

Sri Nugroho, H. dan D.R. Fimmastuti; December, 2020, "Elite and Empowerment of Local Communities: The Dilemma Between Participation and Mobilization in The Era of Democracy", Journal of Governance. Volume 5 Issue 2: 249-265

Sunarto, Kamanto, 2004, Pengantar Sosiologi: Edisi Revisi. Jakarta: Lembaga Penerbit Fakultas Ekonomi Universitas Indonesia..

Suseno, F M., 2010. Pemikiran Karl Marx: Dari Sosialisme Utopis ke Perselisihan Revisionisme. Jakarta: Gramedia Pustaka Utama.

Takbir, M., 2018, "Negosiasi Antara Tradisi dan Modernitas Di Pesantren As'adiyah Sengkang Sulawesi Selatan", Kenosis: Jurnal Kajian Teologi; Vol 4, No 2: 220-233.

Tracy, S; 2013, Qualitative Research Methods: Collecting Evidence, Crafting Analysis, Communicating Impact; Chichester, West Sussex,: A John Wiley \& Sons, Ltd., Publication

Wahyono, E, 2017, "Stratifikasi Sosial pada Masyarakat Pedesaan di Jawa Abad ke-19"; Seminar Nasional Riset Inovatif,: 305-312.

Williams, R, 1977. Marxism and Literature, Oxford, NY: Oxford University.

Yin, RK, 2011; Qualitative Research from Start to Finish; New York: The Guilford Press 